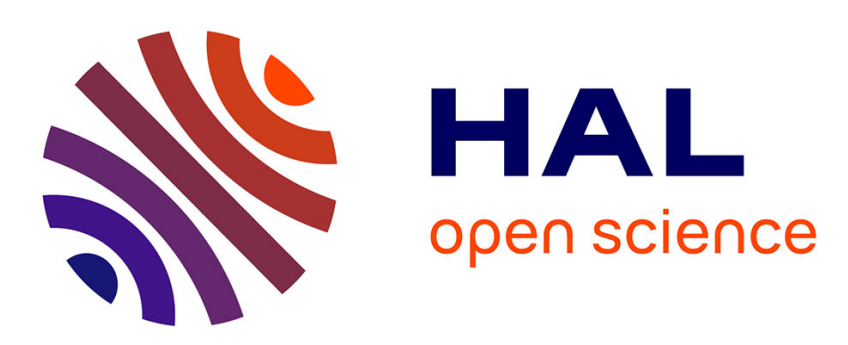

\title{
An Improved Synthesis of Dichloroalkylphosphonates, Chloroalkynes and Terminal Alkynes via Diethyl Dichloromethylphosphonate
}

John Carran, Rachel Waschbüsch, Angela Marinetti, Philippe Savignac

\section{To cite this version:}

John Carran, Rachel Waschbüsch, Angela Marinetti, Philippe Savignac. An Improved Synthesis of Dichloroalkylphosphonates, Chloroalkynes and Terminal Alkynes via Diethyl Dichloromethylphosphonate. Synthesis: Journal of Synthetic Organic Chemistry, 1996, 1996 (12), pp.1494-1498. 10.1055/s1996-4419 . hal-03166566

\section{HAL Id: hal-03166566 \\ https://hal.science/hal-03166566}

Submitted on 11 Mar 2021

HAL is a multi-disciplinary open access archive for the deposit and dissemination of scientific research documents, whether they are published or not. The documents may come from teaching and research institutions in France or abroad, or from public or private research centers.
L'archive ouverte pluridisciplinaire $\mathbf{H A L}$, est destinée au dépôt et à la diffusion de documents scientifiques de niveau recherche, publiés ou non, émanant des établissements d'enseignement et de recherche français ou étrangers, des laboratoires publics ou privés. 


\title{
An Improved Synthesis of Dichloroalkylphosphonates, Chloroalkynes and Terminal Alkynes via Diethyl Dichloromethylphosphonate
}

\author{
John Carran, Rachel Waschbüsch, Angela Marinetti, Philippe Savignac
}

Hétéroatomes et Coordination, URA CNRS 1499, DCPH, Ecole Polytechnique, 91128

Palaiseau Cedex, France.

Diethyl 1,1-dichloromethylphosphonate (2) was synthesised in good yield from the reduction of 1,1,1-trichloromethylphosphonate (1) with $i$ - $\mathrm{C}_{3} \mathrm{H}_{7} \mathrm{MgCl}$ and subsequent hydrolysis. The reactivity of 2 towards $\alpha$-alkylation and its utility in the synthesis of chloroalkynes and terminal alkynes was investigated.

1,1-Dichloromethylphosphonate (2) is a useful Wittig-Horner olefination reagent giving dichloroalkenes on reaction with carbonyl compounds. ${ }^{1-4}$ Suitable dichloroalkenes are in turn potential intermediates in the synthesis of chloroalkynes and terminal alkynes via elimination reactions. ${ }^{4}$ Given its wide synthetic potential an optimized large scale synthesis of 1,1-dichloromethylphosphonate using simple, cheap, and easily available materials with the minimum of purification requirements is desired. This compound was first synthesised by Cadogan ${ }^{5}$ but in moderate yield $(65 \%)$ and in the presence of side products which make purification difficult. Attempts to synthesise this target compound by means of the Michaelis-Arbuzov reaction between triethyl phosphite and chloroform failed to yield any product even under forcing conditions. ${ }^{6}$

1,1,1-Trichloromethylphosphonate (1), which is commercially available and readily prepared on laboratory scale, ${ }^{7}$ has been envisaged by many authors as a synthetic precursor for 1,1dichloromethylphosphonate. This group and other researchers have attempted optimisation of the synthesis of $\mathbf{2}$ from 1. Various approaches have been tried, e.g. abstraction or exchange of one chlorine atom with a base or reductive procedures. Thus, the reactions of 1 with covalent organic bases (such as $(\mathrm{EtO})_{3} \mathrm{P}^{5}$ and $\left(\mathrm{Me}_{2} \mathrm{~N}\right)_{3} \mathrm{P}$ ) and charged organic bases (such as $n^{-1,4}$ and 
$s$-BuLi), with tributyl tin hydride, $\mathrm{Cl}_{3} \mathrm{SiH} / \mathrm{Et}_{3} \mathrm{~N}^{8}$, and molecular hydrogen have been studied. In each of these cases the reaction gave the required product $\mathbf{2}$, often in reasonable yield, but always in the presence of undesirable side-products.

Table 1. Synthesis of Diethyl 1,1-Dichloromethylphosphonate 2 from 1.

\begin{tabular}{|c|c|c|}
\hline Base Used & Conditions & Yield $(\%)$ \\
\hline$n$-BuLi & $-78^{\circ} \mathrm{C}, \mathrm{THF}, 3 \mathrm{M} \mathrm{HCl}$ quench & $85^{\mathrm{a}}$ \\
\hline$n$-BuLi & $\begin{array}{l}\mathrm{LiCl} / \mathrm{LiBr} \text { addn., } 3 \mathrm{M} \mathrm{HCl} \\
\text { quench }\end{array}$ & $85^{\mathrm{a}}$ \\
\hline$s$-BuLi & $\begin{array}{l}-78^{\circ} \mathrm{C}, \mathrm{THF}, \mathrm{EtOH}, 3 \mathrm{M} \mathrm{HCl} \\
\text { quench }\end{array}$ & $80^{\mathrm{a}}$ \\
\hline$s$-BuLi & $\begin{array}{l}\mathrm{LiCl} / \mathrm{LiBr} \text { addn., } 3 \mathrm{M} \mathrm{HCl} \\
\text { quench }\end{array}$ & $80^{\mathrm{a}}$ \\
\hline$(\mathrm{EtO})_{3} \mathrm{P}$ & Hexanol, reflux & 65 \\
\hline$\left(\mathrm{Me}_{2} \mathrm{~N}\right) 3 \mathrm{P}$ & $\begin{array}{l}\text { R.T., THF, EtOH, } 4 \mathrm{M} \mathrm{HCl} \\
\text { quench }\end{array}$ & $92^{\mathrm{a}}$ \\
\hline$i-\mathrm{PrMgCl}$ & $-78^{\circ} \mathrm{C}, \mathrm{THF}, 3 \mathrm{M} \mathrm{HCl}$ quench & 94 \\
\hline
\end{tabular}

a obtained in the presence of non-separable side-products

In the reaction between $(\mathrm{EtO})_{3} \mathrm{P}$ and $\mathbf{1}$ in hexanol as solvent and proton source, $\mathbf{2}$ is formed jointly with hexyl diethyl phosphate $\left((\mathrm{EtO})_{2} \mathrm{P}(\mathrm{O}) \mathrm{OHex}\right)$, which is very difficult to eliminate. In the case of $\left(\mathrm{Me}_{2} \mathrm{~N}\right)_{3} \mathrm{P}$ (Table 1) the final product 2 , isolated after reduction at room temperature with EtOH as protonating agent, is contaminated with $\left(\mathrm{Me}_{2} \mathrm{~N}\right)_{3} \mathrm{P}(\mathrm{O})(6-8 \%)$ despite several acidic washings. With $\mathrm{Cl}_{3} \mathrm{SiH}$ and $\mathrm{Et}_{3} \mathrm{~N}$ in $\mathrm{C}_{6} \mathrm{H}_{6}$ at room temperature the reduction is complete but $\mathrm{SiCl}_{4}$ is formed which is difficult to remove in a large scale synthesis without degradation of the desired phosphonate $\mathbf{2}$. When $\mathbf{1}$ was subjected to catalytic hydrogenation in EtOH over a palladium catalyst or reduction with $\mathrm{Bu}_{3} \mathrm{SnH}$ in $\mathrm{THF}$ the desired product was obtained in a non-separable mixture of dichloro-, monochloro-, and methylphosphonates. The lithium-chlorine exchange reaction by means of alkyl lithium reagents in $\mathrm{THF}$ at $-78^{\circ} \mathrm{C}$ (with or without the addition of lithium salts) (Table 1) results in the formation of many different side-products (generally four or five are detected by ${ }^{31} \mathrm{P}$ NMR spectroscopy) which are again inseparable from the desired compound $\mathbf{2}$. These side-products can be assumed to arise from unfavourable reactions between the strong nucleophilic base and the phosphorus moiety and/or formation of the carbene via halogen abstraction from the unstable carbanion. Finally, we found that by using isopropyl-magnesium chloride at low 
temperature and by conducting the hydrolysis with ethanolic $\mathrm{HCl}$, pure $\mathbf{2}$ could be obtained on a molar scale in $94 \%$ yield from 1 (Scheme 1). ${ }^{9}$

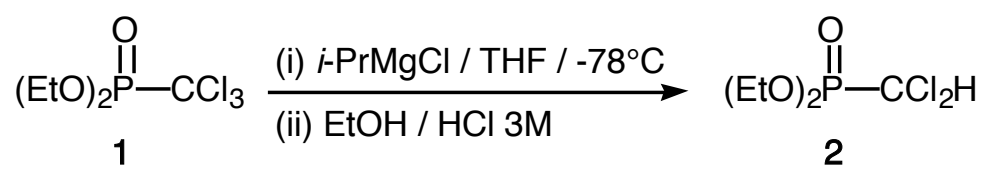

\section{Scheme 1}

The use of the Grignard reagent favours the metal-halogen exchange reaction and avoids problems such as attack at phosphorus and carbene formation because of the increased thermal stability of the dichloroanion. This synthesis is much more efficient than those previously reported and fulfills our previous requirements by :

a) Utilizing a stable, cheap and widely available laboratory reagent.

b) Giving an easily eliminable co-product $\left(i-\mathrm{C}_{3} \mathrm{H}_{7} \mathrm{Cl}\right)$.

c) The final product being easily purified by means of a simple distillation and obtained in greater than $90 \%$ yield.

We then conducted a series of experiments with $\mathbf{2}$ to optimise its reactivity and potential in organic synthesis. Two types of reactions were considered: metalation-alkylation, leading to $\alpha$-alkylmethylphosphonates, ${ }^{10}$ and Wittig-Horner like reactions with aldehydes. Both sets of experiments were conducted in mild, internal quenching conditions in order to trap the unstable dichloroanion derived from $\mathbf{2}$. However the magnesium derivative of $\mathbf{2}$ is neither sufficiently basic nor nucleophilic to undergo further alkylation or olefination reactions, it has been replaced by the more powerful lithium reagent. By simultaneous addition of the phosphonate reactant and the prospective electrophile to the lithiated base the lifetime of the carbanion is very short and carbene formation via chloride elimination is thus avoided.

Addition of dichloromethylphosphonate $\mathbf{2}$ and the alkyl halide to LiHMDS at low temperature led to the alkylphosphonates 3a-h in yields ranging from $67 \%$ to $97 \%$ (Scheme 2, Table 2).

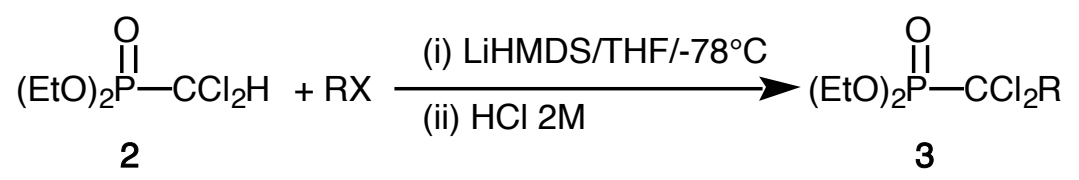

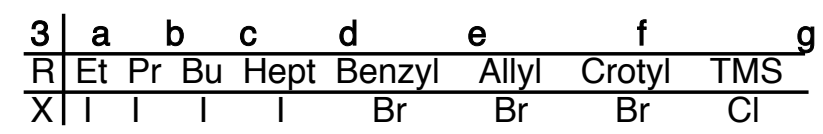

\section{Scheme 2}


Table 2. Synthesis of Diethyl 1,1-Dichloroalkylphosphonates 3a-h

\begin{tabular}{ccccc}
\hline $\begin{array}{c}\text { Product } \\
\mathbf{3}\end{array}$ & $\begin{array}{c}\text { 31P NMR }\left(\mathrm{CDCl}_{3}\right) \\
\mathbf{a}^{\mathrm{b}}\end{array}$ & bp $\left({ }^{\circ} \mathrm{C}\right) /$ Torr & $\begin{array}{c}\text { Yield }^{\mathrm{a}}(\%) \\
\text { (reported yield) }\end{array}$ & Molecular formula $^{\mathrm{f}}$ \\
$\mathbf{b}^{\mathrm{b}}$ & $12.9^{15}$ & $150 / 20$ & 93 & $\mathrm{C}_{7} \mathrm{H}_{15} \mathrm{Cl}_{2} \mathrm{O}_{3} \mathrm{P}(249.1)$ \\
$\mathbf{c}^{\mathrm{b}}$ & $12.6^{15}$ & $95 / 0.6$ & 88 & $\mathrm{C}_{8} \mathrm{H}_{17} \mathrm{Cl}_{2} \mathrm{O}_{3} \mathrm{P}(263.1)$ \\
$\mathbf{d}^{\mathrm{b}}$ & $12.5^{15}$ & $101 / 0.6$ & 97 & $\mathrm{C}_{9} \mathrm{H}_{19} \mathrm{Cl}_{2} \mathrm{O}_{3} \mathrm{P}(277.1)$ \\
$\mathbf{e}^{\mathrm{c}}$ & 12.8 & $230 / 20$ & 94 & $\mathrm{C}_{12} \mathrm{H}_{25} \mathrm{Cl}_{2} \mathrm{O}_{3} \mathrm{P}(319.2)$ \\
$\mathbf{f}^{\mathrm{c}}$ & 11.9 & $170 / 0.6$ & 92 & $\mathrm{C}_{12} \mathrm{H}_{17} \mathrm{Cl}_{2} \mathrm{O}_{3} \mathrm{P}(311.1)$ \\
$\mathbf{g}^{\mathbf{c}}$ & $12.4^{15}$ & $152 / 20$ & 67 & $\mathrm{C}_{8} \mathrm{H}_{15} \mathrm{Cl}_{2} \mathrm{O}_{3} \mathrm{P}(261.1)$ \\
$\mathbf{h}^{\mathrm{d}, \mathrm{e}}$ & $12.5^{15}$ & $140 / 20$ & 87 & $\mathrm{C}_{9} \mathrm{H}_{17} \mathrm{Cl}_{2} \mathrm{O}_{3} \mathrm{P}(275.1)$ \\
\hline
\end{tabular}

a Yield of distilled products

b Synthesised from RI

c Synthesised from RBr

d Synthesised from RCl

e Decomposes on work up

f The microanalyses were in satisfactory agreement with the calculated values; maximum deviation found : C, $\pm 0.19 ; \mathrm{H}, \pm 0.22$.

LiHMDS was selected because it is a fairly weak, sterically hindered base which specifically forms the anion of the dichloromethylphosphonate by proton abstraction and avoids the problems of more nucleophilic, less hindered bases such as $n$-BuLi, i.e. the formation of unwanted side products from nucleophilic attack on the phosphorus moiety. The instantaneous formation and reaction between the unstable anion and the electrophile leads to high yields of pure products via a simple experimental procedure. The process is a one-pot reaction which shows no traces of anion decomposition (the characteristic darkening of the reaction medium typical of these unstable anions) and no special preparation of reagents is required. In all cases, except those of allyl bromide and crotyl bromide, the above reaction smoothly proceeds to give the required alkylated product $\mathbf{3}$ in about $90 \%$ yield. With allyl bromide and crotyl bromide a competing side-reaction appears to occur under the conditions used (the respective iodides gave similar results). The side product, which is present as a series of small peaks in the vinylic portion of the ${ }^{1} \mathrm{H}$ spectrum, is supposed to be an elimination product formed by reaction of the small amount of excess base with the intermediate allyl phosphonate. When 2.3 equivalents of LiHMDS were used in the reaction the side product was observed in greater proportion than before. The elimination product is usually formed in less than $5 \%$ yield under the conditions employed and can be removed by careful distillation under water pump pressure. Quantitative formation of the trimethylsilyl substituted derivative $\mathbf{3 h}$ was observed by ${ }^{31} \mathrm{P}$ NMR spectroscopy $(\delta(\mathrm{THF})=12.9 \mathrm{ppm})$ of the reaction mixture prior to hydrolysis, on reaction of $\mathbf{1}$ with chlorotrimethylsilane at low 
temperature. Compound $\mathbf{3 h}$ proved to be fragile and decomposed after hydrolysis with $\mathrm{HCl}$ to a mixture of several compounds giving major peaks in the ${ }^{31} \mathrm{P}$ NMR spectrum at 23.0, $15.3,10.5$, and $-1.0 \mathrm{ppm}$.

We next examined the synthesis of chloroacetylenes by reaction of the anion of $\mathbf{2}$ with aldehydes. A variety of chloroacetylenes (5a-e) were synthesized under internal quench conditions by using 2.2 equivalents of a lithium amide (acting successively as metalating agent and as base) (Scheme 3).

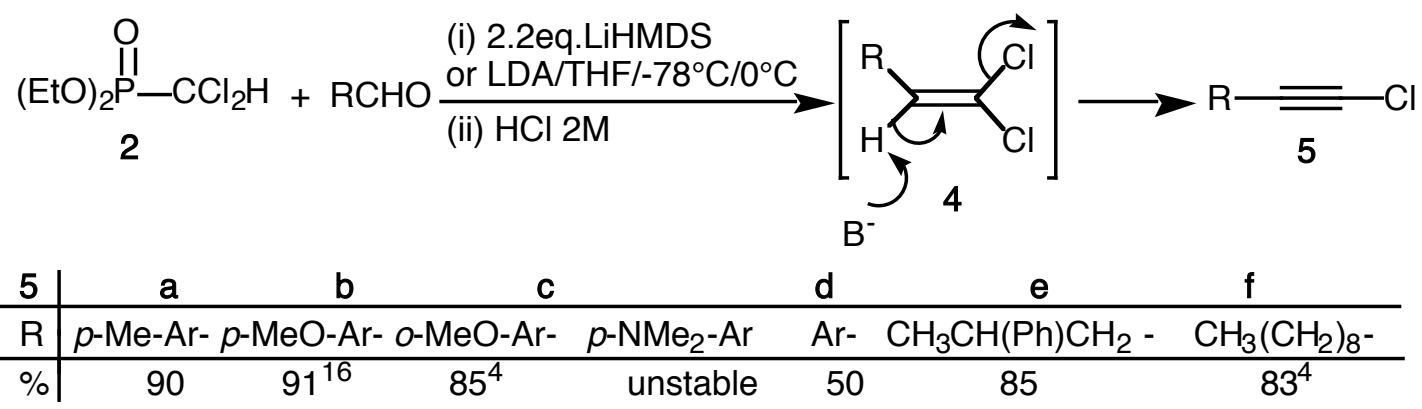

$5 \mathrm{f}$ and $5 \mathrm{~g}$ were formed by the reaction of $4 \mathrm{f}$ and $4 \mathrm{~g}$ with one equivalent of LDA

\section{Scheme 3}

The initial step is a classical Wittig-Horner reaction between the phosphonate carbanion and the aldehyde giving the gem dichloroolefin 4 . The second step, which occurs on warming, is a trans elimination affording chloroacetylene 5. LiHMDS is a well suited base for the clean conversion of aromatic aldehydes into the corresponding chloroacetylenes however it was insufficiently strong enough to effect the trans elimination of $\mathrm{HCl}$ when aliphatic aldehydes were used as starting materials. Thus, the gem-dichloroolefins $\mathbf{4 f}$ and $\mathbf{4 g}$ were obtained as the sole products (60-80\% yield) in the reactions with phenylpropionaldehyde and decanal with LiHMDS as base. The corresponding chloroacetylenes $\mathbf{5 f}$ and $\mathbf{5 g}$ could be obtained from these compounds by further reaction with one equivalent of LDA or directly from dichloromethyl phosphonate and the above aldehydes in the presence of 2.2 equivalents of LDA. Alkynes 5a-g are moderately stable in their pure state and should be stored at $-10^{\circ} \mathrm{C}$.

Reaction of a mixture of $\mathbf{2}$ and an aldehyde in internal quench conditions with one equivalent of LDA in THF at $-78^{\circ} \mathrm{C}$ followed by addition of 2.1 equivalents of $n$-BuLi at $-78^{\circ} \mathrm{C}$ affords compounds 7a-e in high yields and high degrees of purity after careful acidic hydrolysis $(\mathrm{pH}$ 5-6) (Scheme 4). BuLi is supposed to effect the chlorine-lithium exchange reaction on the intermediate dichloroolefin 4 and LDA, reformed from the second equivalent of $n$-BuLi, to effect the elimination reaction leading to the lithiated alkyne 6. LiHMDS is not a strong enough base to act in this manner whatever the nature of the aldehyde. 


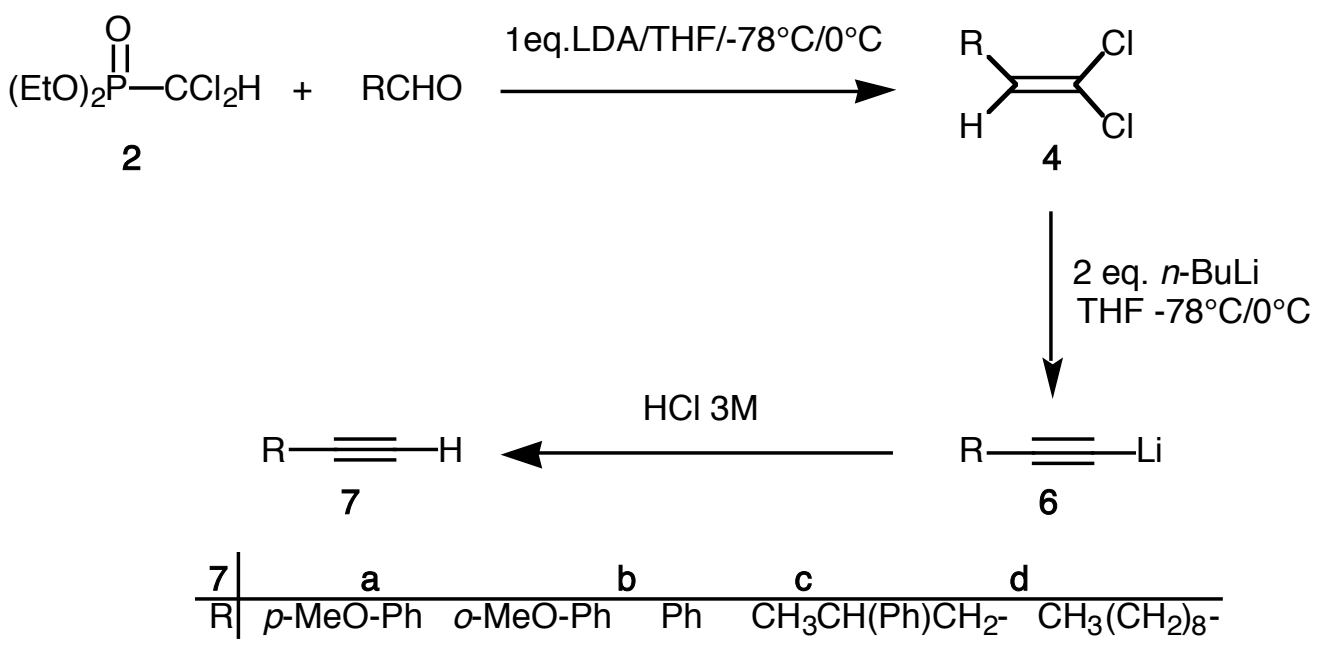

\section{Scheme 4}

Table 3. Synthesis of Alkenes 7a-e

\begin{tabular}{cccl}
\hline Product 7 & bp $\left({ }^{\circ} \mathrm{C}\right) /$ Torr & Yield $^{\mathrm{a}}(\%)$ & Molecular formula $^{\mathrm{b}}$ \\
\hline $\mathbf{a}$ & $118 / 20^{17}$ & 84 & $\mathrm{C}_{9} \mathrm{H}_{8} \mathrm{O}(132.2)$ \\
b & $115 / 20^{18}$ & 72 & $\mathrm{C}_{9} \mathrm{H}_{8} \mathrm{O}(132.2)$ \\
c & $51 / 20^{19}$ & 57 & $\mathrm{C}_{8} \mathrm{H}_{6}(102.1)$ \\
d & $140 / 20$ & 69 & $\mathrm{C}_{11} \mathrm{H}_{22}(144.2)$ \\
e & $95 / 20^{20}$ & 73 & $\mathrm{C}_{11} \mathrm{H}_{20}(152.3)$ \\
\hline
\end{tabular}

a Yield of distilled products

$\mathrm{b}$ The microanalyses were in agreement with the calculated values; maximum deviation found : $\mathrm{C}, \pm 0.05 ; \mathrm{H}$, \pm 0.06 .

Alkynes 7a-c were unstable in crude form and rapidly decomposed at room temperature. We found that the decomposition could be somewhat reduced by keeping the alkynes as solutions in hexane if they are not to be purified or used immediately. Alkynes $\mathbf{7 d}$ and $\mathbf{7 e}$ were found to be relatively stable in their pure form and could be conserved in the refrigerator without significant decomposition. Alternative synthesis of terminal acetylenes from aldehydes have been reported previously by Corey and Fuchs using the reagent couple $\mathrm{Ph}_{3} \mathrm{P}_{/} \mathrm{CBr}_{4},{ }^{11}$ and by both Colvin et al and Gilbert and Weerasooriya using dimethyl diazomethylphosphonate. ${ }^{12,13}$ The amount of triphenylphosphine involved and of triphenylphosphine oxide formed in the former reaction and the difficult and hazardous preparation of the reagent in the latter are obstacles for large scale synthesis. By contrast the present route, which is a modification of the Villieras approach, ${ }^{4}$ (which can occasionally give mixtures of compounds as reported recently by Lowen and Almond), ${ }^{14}$ seems well suited for the synthesis of a wide variety of pure acetylenic compounds on a large scale. 
It is clear from the above results that we now have at our disposal a large scale, high yielding preparation of $\mathbf{2}$, an extremely useful synthetic reagent.

The correct choice of deprotonating agent according to its basicity, ( $n$-BuLi, LiHMDS, LDA) when applied together with internal quench conditions to reactions of $\mathbf{2}$, controls the selective formation of gem dichloroolefins, chloroalkynes and alkynes, in high yields and one pot procedures without formation of side products. All these useful reagents can now be accessed on preparative scale by the above procedures from 2 .

NMR spectra were recorded on a Bruker AC 200 spectrometer operating at $200 \mathrm{MHz}$ for proton, $50.3 \mathrm{MHz}$ for carbon and $81.01 \mathrm{MHz}$ for phosphorus. ${ }^{31} \mathrm{P}$ downfield shifts $(\delta)$ are expressed with a positive sign, in ppm, relative to external $85 \% \mathrm{H}_{3} \mathrm{PO}_{4}$ in $\mathrm{H}_{2} \mathrm{O} .{ }^{1} \mathrm{H}$ and ${ }^{13} \mathrm{C}$ chemical shifts ( $\delta$ ) are reported in ppm relative to $\mathrm{CDCl}_{3}$ as internal standard. Coupling constants $(\mathrm{J})$ are given in Hertz. The following abbreviations are used: s, d, t, q, m for singlet, doublet, triplet, quadruplet and multiplet respectively. Organic solvents were purified by standard procedures. THF was distilled under an inert atmosphere from purple solutions of sodium: benzophenone ketyl. The synthesis of all compounds were carried out under dry nitrogen.

\section{Diethyl 1,1-Dichloromethylphosphonate 2:}

To a stirred mixture of previously standardised $1.9 \mathrm{M}$ solution of isopropylmagnesium chloride $(83 \mathrm{ml} ; 158$ mmol) and THF $(400 \mathrm{ml})$ cooled to $-78^{\circ} \mathrm{C}$, was added dropwise a solution of diethyl 1,1,1trichloromethylphosphonate $(38.3 \mathrm{~g} ; 150 \mathrm{mmol})$ in THF $(50 \mathrm{ml})$ over a period of $15 \mathrm{~min}$ The resulting mixture was stirred at $-78^{\circ} \mathrm{C}$ for a further $15 \mathrm{~min}$ and then a solution of absolute ethanol (12 g; $\left.260 \mathrm{mmol}\right)$ in THF (15 $\mathrm{ml}$ ) was added dropwise to the reaction mixture. After $5 \mathrm{~min}$ the mixture was allowed to warm to $-40^{\circ} \mathrm{C}$ and was then poured into a beaker containing a mixture of $3 \mathrm{M} \mathrm{HCl}(70 \mathrm{ml})$, an equal volume of crushed ice, and $\mathrm{CH}_{2} \mathrm{Cl}_{2}$. The phases were separated and the aqueous phase was extracted with $\mathrm{CH}_{2} \mathrm{Cl}_{2}(60 \mathrm{ml} \mathrm{X} \mathrm{2)}$. The combined organic phases were dried over $\mathrm{MgSO}_{4}$, filtered and evaporated to yield a yellow oil which when distilled gave the title compound as a colourless oil. $\left(32 \mathrm{~g}, 94 \%\right.$; b.p. $133^{\circ} \mathrm{C}$ at $\left.10 \mathrm{~mm} \mathrm{Hg}\right) . \delta{ }^{31} \mathrm{P}\left(\mathrm{CDCl}_{3}\right)+11.1 . n_{\mathrm{D}}{ }^{25} 1.4513$. $\begin{array}{llrr}\mathrm{C}_{5} \mathrm{H}_{11} \mathrm{Cl}_{2} \mathrm{O}_{3} \mathrm{P} & \text { calc. } & \mathrm{C} 27.17 & \mathrm{H} 5.02 \\ (221.02) & \text { found } & 27.38 & 4.91\end{array}$

\section{Diethyl 1,1-Dichloroalkylphosphonates 3a-f from Alkyl Iodides and Bromides; General Procedure:}

To a stirred mixture of a previously standardised $1.38 \mathrm{M}$ solution of $n$-BuLi (16 ml; $22 \mathrm{mmol}$ ) and THF (20 ml) at $-78^{\circ} \mathrm{C}$ was added a solution of HMDS $(3.7 \mathrm{~g} ; 23 \mathrm{mmol})$ in THF $(10 \mathrm{ml})$ dropwise over several minutes. The reaction mixture was stirred at $-78^{\circ} \mathrm{C}$ for $15 \mathrm{~min}$ and then a mixture of diethyl 1,1-dichloromethylphosphonate $(4.42 \mathrm{~g} ; 20 \mathrm{mmol})$ and the alkyl halide $(25 \mathrm{mmol})$ in THF $(10 \mathrm{ml})$ were added dropwise maintaining the reaction temperature at $-78^{\circ} \mathrm{C}$. After the addition was complete the reaction mixture was stirred for $15 \mathrm{~min}$ at $-78^{\circ} \mathrm{C}$ and then allowed to warm to $-20^{\circ} \mathrm{C}$. $2 \mathrm{M} \mathrm{HCl}(20 \mathrm{ml})$ was then added and the mixture stirred for a further $10 \mathrm{~min}$ The phases were separated and the aqueous phase was extracted with $\mathrm{CH}_{2} \mathrm{Cl}_{2}(2 \times 30 \mathrm{ml})$. The combined 
organic phases were dried over $\mathrm{MgSO}_{4}$, filtered and evaporated to yield an oil which when distilled gave the title compounds as colourless to pale yellow oils.

\section{1- Alkyl or 1-Aryl-2-chloroalkynes 5a-g; General Procedure:}

To a stirred mixture of a previously standardised 1.38 M solution of $n$-BuLi (37 ml, $50 \mathrm{mmol})$ and THF (40 ml) at $-78^{\circ} \mathrm{C}$ was added a solution of $\operatorname{HMDS}(8.96 \mathrm{~g}, 56 \mathrm{mmol}$, with aromatic aldehydes), or a solution of diisopropylamine (5.66 g, $56 \mathrm{mmol}$, with aliphatic aldehydes) in THF (20 ml) dropwise over several minutes. The reaction mixture was stirred at $-78^{\circ} \mathrm{C}$ for $15 \mathrm{~min}$ and then a mixture of diethyl 1,1dichloromethylphosphonate $(4.42 \mathrm{~g} ; 20 \mathrm{mmol})$ and the aldehyde $(20 \mathrm{mmol})$ in THF $(10 \mathrm{ml})$ was added dropwise maintaining the temperature at $-78^{\circ} \mathrm{C}$. After stirring for $15 \mathrm{~min}$ the temperature was allowed to rise to $0^{\circ} \mathrm{C}$ and the mixture was stirred for two hours at this temperature. Water $(20 \mathrm{ml})$ was then added dropwise, the phases separated and the aqueous phase washed with dichloromethane $(2 \times 30 \mathrm{ml})$. The combined organic phases were dried over $\mathrm{MgSO}_{4}$, filtered and evaporated on a rotary evaporator. The crude residue was then passed through a silica plug with hexane as eluent to obtain the title compounds as mobile oils.

\section{Arylalkynes 7a-e; General Procedure:}

To a $1.5 \mathrm{M}$ sol; of $n-\mathrm{BuLi}(14 \mathrm{ml} ; 21 \mathrm{mmol})$ cooled to $-20^{\circ} \mathrm{C}$ is added a solution of diisopropylamine $(2.23 \mathrm{~g} ; 22$ $\mathrm{mmol})$ in THF $(30 \mathrm{ml})$ dropwise with stirring over $15 \mathrm{~min}$ The resulting clear solution is then cooled to $-78^{\circ} \mathrm{C}$ and a solution of diethyl 1,1-dichloromethylphosphonate (4.42 g; $20 \mathrm{mmol})$, and the aldehyde (20 mmol) in THF $(30 \mathrm{ml})$ is added dropwise over a $30 \mathrm{~min}$ interval. The resulting red solution is then stirred at $-78^{\circ} \mathrm{C}$ for a further $30 \mathrm{~min}$ and then allowed to slowly warm to $0^{\circ} \mathrm{C}$. The now brown reaction mixture is then cooled to $-78^{\circ} \mathrm{C}$ and a $1.5 \mathrm{M}$ solution of $n$ - $\mathrm{BuLi}(28 \mathrm{ml} ; 42 \mathrm{mmol})$ is added dropwise over $30 \mathrm{~min}$ The solution is once again allowed to warm to $0^{\circ} \mathrm{C}$ and is then quenched by the dropwise addition of $3 \mathrm{M} \mathrm{HCl}(30 \mathrm{ml})$ until the solution is $\mathrm{pH} 5-6$. The phases are separated and the aqueous phase is extracted with diethyl ether $(2 \mathrm{X} 50 \mathrm{ml})$. The combined organic phases are then washed with water $(10 \mathrm{ml})$ and dried over $\mathrm{MgSO}_{4}$ and then filtered and evaporated. The crude alkynes are then distilled to give the title compounds as pure colourless oils.

Table 4. ${ }^{1} \mathrm{H}$ and ${ }^{13} \mathrm{C}$ NMR Data of Diethyl 1,1-Dichloromethylphosphonate 2

\begin{tabular}{ll}
\hline${ }^{1} \mathrm{H}$ NMR $\left(\mathrm{CDCl}_{3}, 200 \mathrm{MHz}\right) \delta, J(\mathrm{~Hz})$ & ${ }^{13} \mathrm{C} \mathrm{NMR}_{\left(\mathrm{CDCl}_{3}, 50 \mathrm{MHz}\right) \delta, J \mathrm{C}, \mathrm{P}(\mathrm{Hz})}$ \\
\hline $1.3\left(\mathrm{t}, \mathrm{J}=7,6 \mathrm{H}, \underline{\mathrm{CH}}_{\underline{3}} \mathrm{CH}_{2} \mathrm{O}\right), 4.15-4.4\left(\mathrm{~m}, 4 \mathrm{H}, \mathrm{OCH}_{2}\right)$, & $16.02\left(\underline{\mathrm{CH}}_{\underline{3}} \mathrm{CH}_{2} \mathrm{O}\right), 58.51-63.04\left(\mathrm{~d}, \mathrm{~J}=178, \mathrm{CCl}_{2}\right)$, \\
$5.65\left(\mathrm{~d}, \mathrm{~J}=2,1 \mathrm{H}, \mathrm{CCl}_{2} \mathrm{H}\right)$ & $64.60\left(\mathrm{CH}_{3} \underline{\mathrm{CH}}_{2} \mathrm{O}\right)$ \\
\hline
\end{tabular}


Table 5. ${ }^{1} \mathrm{H}$ and ${ }^{13} \mathrm{C}$ NMR Data of Diethyl 1,1-Dichloroalkylphosphonates 3a-f

\begin{tabular}{|c|c|c|}
\hline $\begin{array}{l}\text { Prod- } \\
\text { uct } \mathbf{3}\end{array}$ & ${ }^{1} \mathrm{H} \mathrm{NMR}\left(\mathrm{CDCl}_{3}, 200 \mathrm{MHz}\right)$ & $\begin{array}{l}{ }^{13} \mathrm{C} \mathrm{NMR}\left(\mathrm{CDCl}_{3}, 50 \mathrm{MHz}\right) \\
\delta, J \mathrm{C}, \mathrm{P}(\mathrm{Hz})\end{array}$ \\
\hline $\mathbf{a}$ & $\begin{array}{l}1.23\left(\mathrm{t}, \mathrm{J}=7,3 \mathrm{H}, \underline{\mathrm{CH}_{3}} \mathrm{CH}_{2}\right), 1.3(\mathrm{t}, \mathrm{J}=7,6 \mathrm{H}, \\
\left.\mathrm{CH}_{\underline{3}} \mathrm{CH}_{2} \mathrm{O}\right), 2.2-2.4\left(\mathrm{~m}, 2 \mathrm{H}, \underline{\mathrm{CH}}_{2} \mathrm{CH}_{3}\right), 4.15- \\
4.4\left(\mathrm{~m}, 4 \mathrm{H}, \mathrm{OCH}_{2}\right)\end{array}$ & $\begin{array}{llll}7.97 & \left(\underline{\mathrm{CH}_{3}} \mathrm{CH}_{2}\right), & 16.34\left(\underline{\mathrm{CH}_{3}} \mathrm{CH}_{2} \mathrm{O}\right), & 35.97 \\
\left(\mathrm{CH}_{3} \underline{\mathrm{CH}}_{2}\right), & 65.22 & \left(\mathrm{CH}_{3} \underline{\mathrm{CH}}_{2} \mathrm{O}\right), 84 \quad(\mathrm{~d}, \quad \mathrm{~J}=179, \\
\left.\mathrm{PCCl}_{2}\right) & & & \end{array}$ \\
\hline b & $\begin{array}{l}0.9\left(\mathrm{t}, \mathrm{J}=7,3 \mathrm{H}, \underline{\mathrm{CH}_{3}}\left(\mathrm{CH}_{2}\right)_{2}\right), 1.3(\mathrm{t}, \mathrm{J}=7,6 \mathrm{H}, \\
\left.\underline{\mathrm{CH}}_{3} \mathrm{CH}_{2} \mathrm{O}\right), 1.6-1.8\left(\mathrm{~m}, 2 \mathrm{H}, \mathrm{CH}_{2}\right), 2.1-2.3(\mathrm{~m}, \\
\left.2 \mathrm{H}, \mathrm{CH}_{2}\right), 4.15-4.4\left(\mathrm{~m}, 4 \mathrm{H}, \mathrm{OCH}_{2}\right)\end{array}$ & $\begin{array}{l}13.55\left(\underline{\mathrm{CH}_{3}}\left(\mathrm{CH}_{2}\right)_{2}\right), \quad 16.48\left(\underline{\mathrm{CH}_{3}} \mathrm{CH}_{2} \mathrm{O}\right), 17.16 \\
\left(\mathrm{CH}_{2}\right), 44.61\left(\mathrm{CH}_{2}\right), \\
85.25\left(\mathrm{~d}, \mathrm{~J}=178, \mathrm{CCl}_{2}\right)\end{array}$ \\
\hline c & $\begin{array}{l}0.9\left(\mathrm{t}, \mathrm{J}=7,3 \mathrm{H}, \underline{\mathrm{CH}_{3}}\left(\mathrm{CH}_{2}\right)_{3}\right), 1.2-1.4(\mathrm{~m}, 2 \mathrm{H}, \\
\left.\mathrm{CH}_{2}\right), 1.3\left(\mathrm{t}, \mathrm{J}=7,6 \mathrm{H}, \underline{\mathrm{CH}}_{3} \mathrm{CH}_{2} \mathrm{O}\right), 1.6-1.8(\mathrm{~m}, \\
\left.2 \mathrm{H}, \mathrm{CH}_{2}\right), 2.15-2.3\left(\mathrm{~m}, 2 \mathrm{H}, \mathrm{CH}_{2}\right), 4.15-4.4(\mathrm{~m}, \\
\left.4 \mathrm{H}, \mathrm{OCH}_{2}\right)\end{array}$ & $\begin{array}{llll}13.68 & \left(\underline{\mathrm{CH}}_{3}\left(\mathrm{CH}_{2}\right)_{3}\right), \quad 16.27 \quad\left(\underline{\mathrm{CH}_{3}} \mathrm{CH}_{2} \mathrm{O}\right), & 21.91 \\
\left(\mathrm{CH}_{2}\right), & 25.58 \quad\left(\mathrm{CH}_{2}\right), \quad 42.06 \quad\left(\mathrm{CH}_{2}\right), & 65.16 \\
\left(\mathrm{CH}_{3} \underline{\mathrm{CH}}_{2} \mathrm{O}\right), 81.54-85.12\left(\mathrm{~d}, \mathrm{~J}=178, \mathrm{CCl}_{2}\right) & \end{array}$ \\
\hline d & $\begin{array}{l}0.9\left(\mathrm{t}, \mathrm{J}=7,3 \mathrm{H}, \underline{\mathrm{CH}_{3}}\left(\mathrm{CH}_{2}\right)_{2}\right), 1.15-1.3(\mathrm{~m}, \mathrm{xH}, \\
\left.\mathrm{CH}_{2}\right), 1.3\left(\mathrm{t}, \mathrm{J}=7,6 \mathrm{H}, \underline{\mathrm{CH}}_{3} \mathrm{CH}_{2} \mathrm{O}\right), 1.6-1.9(\mathrm{~m}, \\
\left.\mathrm{xH}, \mathrm{CH}_{2}\right), 2.2-2.4\left(\mathrm{~m}, \mathrm{xH}, \mathrm{CH}_{2}\right), 4.15-4.4(\mathrm{~m}, \\
\left.4 \mathrm{H}, \mathrm{OCH}_{2}\right)\end{array}$ & $\begin{array}{l}14.17\left(\mathrm{CH}_{3}\right), 16.61\left(\mathrm{CH}_{\underline{3}} \mathrm{CH}_{2}\right), 22.71\left(\mathrm{CH}_{2}\right), 23.67 \\
\left(\mathrm{CH}_{2}\right), 29.03\left(\mathrm{CH}_{2}\right), 29.07\left(\mathrm{CH}_{2}\right), 31.81\left(\mathrm{CH}_{2}\right), \\
42.60\left(\mathrm{CH}_{2}\right), 65.39\left(\mathrm{CH}_{3} \underline{\mathrm{CH}_{2}}\right), 81.7(\mathrm{~d}, \mathrm{~J}=179, \\
\left.\mathrm{CCl}_{2}\right)\end{array}$ \\
\hline $\mathbf{e}$ & $\begin{array}{l}1.3\left(\mathrm{t}, \mathrm{J}=7,6 \mathrm{H}, \mathrm{CH}_{3} \mathrm{CH}_{2} \mathrm{O}\right), 3.56(\mathrm{~d}, \mathrm{~J}=6,2 \mathrm{H}, \\
\left.\mathrm{ArCH}_{2}\right), 4.15-4.5\left(\mathrm{~m}, 4 \mathrm{H}, \mathrm{OCH}_{2}\right), 7.2-7.6(\mathrm{~m}, \\
5 \mathrm{H}, \mathrm{Ar})\end{array}$ & 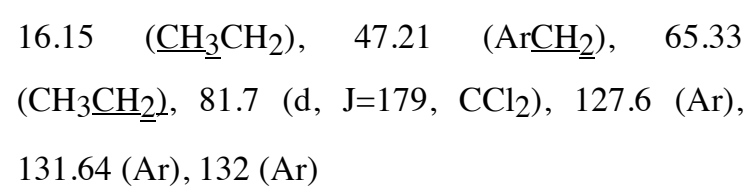 \\
\hline f & $\begin{array}{l}1.3\left(\mathrm{t}, \mathrm{J}=7,6 \mathrm{H}, \mathrm{CH}_{3} \mathrm{CH}_{2} \mathrm{O}\right), 3.0(\mathrm{t}, \mathrm{J}=6,2 \mathrm{H}, \\
\left.\mathrm{CCl}_{2} \mathrm{CH}_{2}\right), 4.15-4.4\left(\mathrm{~m}, 4 \mathrm{H}, \mathrm{OCH}_{2}\right), 5.15-5.4 \\
\left(\mathrm{~m}, 2 \mathrm{H},=\mathrm{CH}_{2}\right), 5.8-6.15(\mathrm{~m}, 1 \mathrm{H},=\mathrm{CH})\end{array}$ & $\begin{array}{l}16.9\left(\underline{\mathrm{CH}_{3}} \mathrm{CH}_{2}\right), 47.13\left(\underline{\mathrm{CH}_{2}} \mathrm{CH}\right), 65.9\left(\mathrm{CH}_{3} \underline{\mathrm{CH}_{2}}\right), \\
81.7\left(\mathrm{~d}, \mathrm{~J}=179, \mathrm{CCl}_{2}\right), 121.75\left(\mathrm{CH}_{2}=\right), 120.88 \\
(\mathrm{CH}=)\end{array}$ \\
\hline
\end{tabular}

Table 6. ${ }^{1} \mathrm{H}$ and ${ }^{13} \mathrm{C}$ NMR Data of Chloroalkynes 5a-g

\begin{tabular}{|c|c|c|}
\hline $\begin{array}{l}\text { Prod- } \\
\text { uct } 5\end{array}$ & $\begin{array}{l}{ }^{1} \mathrm{H} \mathrm{NMR}\left(\mathrm{CDCl}_{3}, 200 \mathrm{MHz}\right) \\
\delta, J(\mathrm{~Hz})\end{array}$ & $\begin{array}{l}{ }^{13} \mathrm{C} \mathrm{NMR}\left(\mathrm{CDCl}_{3}, 50 \mathrm{MHz}\right) \\
\delta, J_{\mathrm{C}, \mathrm{P}(\mathrm{Hz})}\end{array}$ \\
\hline $\mathbf{a}$ & $\begin{array}{l}2.43\left(\mathrm{~s}, 3 \mathrm{H}, \mathrm{CH}_{3}\right), 7.18(\mathrm{~d}, \mathrm{~J}=8,2 \mathrm{H}, \mathrm{Ar}-\mathrm{H}), 7.4 \\
(\mathrm{~d}, \mathrm{~J}=8,2 \mathrm{H}, \mathrm{Ar}-\mathrm{H})\end{array}$ & $\begin{array}{l}21.82\left(\mathrm{CH}_{3}\right), 64.0(\mathrm{Ar}-\mathrm{C} \equiv), 71.0(\equiv \mathrm{C}-\mathrm{Cl}), 119.8 \\
(\mathrm{Ar}), 129.58(\mathrm{Ar}), 132.31(\mathrm{Ar}), 139.17(\mathrm{Ar})\end{array}$ \\
\hline b & $\begin{array}{l}3.9\left(\mathrm{~s}, 3 \mathrm{H}, \mathrm{CH}_{3} \mathrm{O}\right), 6.91(\mathrm{~d}, \mathrm{~J}=8,2 \mathrm{H}, \mathrm{Ar}-\mathrm{H}), \\
7.45(\mathrm{~d}, \mathrm{~J}=8,2 \mathrm{H}, \mathrm{Ar}-\mathrm{H})\end{array}$ & $\begin{array}{l}55.41\left(\mathrm{CH}_{3} \mathrm{O}\right), 67.5(\mathrm{Ar}-\mathrm{C} \equiv), 70.0(\equiv \mathrm{C}-\mathrm{Cl}), 114.3 \\
(\mathrm{Ar}), 123.5(\mathrm{Ar}), 159.8(\mathrm{Ar})\end{array}$ \\
\hline c & $\begin{array}{l}3.8\left(\mathrm{~s}, 3 \mathrm{H}, \mathrm{OCH}_{3}\right), 6.82(\mathrm{t}, \mathrm{J}=9,1 \mathrm{H}, \mathrm{Ar}-\mathrm{H}), \\
7.12-7.35(\mathrm{~m}, 3 \mathrm{H}, \mathrm{Ar}-\mathrm{H})\end{array}$ & $\begin{array}{l}55.85\left(\mathrm{CH}_{3} \mathrm{O}\right), 66.5(\mathrm{Ar}-\mathrm{C} \equiv), 72.2(\equiv \mathrm{C}-\mathrm{Cl}), 111.03 \\
(\mathrm{Ar}), 112.0(\mathrm{Ar}), 120.83(\mathrm{Ar}), 130.51(\mathrm{Ar}), 134.21 \\
(\mathrm{Ar}), 161.12(\mathrm{Ar})\end{array}$ \\
\hline
\end{tabular}


d $\quad 3.08\left(\mathrm{~s}, 6 \mathrm{H},\left(\mathrm{CH}_{3}\right)_{2} \mathrm{~N}\right), 6.7(\mathrm{~d}, \mathrm{~J}=8,2 \mathrm{H}, \mathrm{Ar}-\mathrm{H})$,

$7.4(\mathrm{~d}, \mathrm{~J}=8,2 \mathrm{H}, \mathrm{Ar}-\mathrm{H})$

e $\quad 7.33-7.62(\mathrm{~m}, 5 \mathrm{H}, \mathrm{Ar}-\mathrm{H})$

$68.66(-\mathrm{C} \equiv), 70.12(\equiv \mathrm{C}-\mathrm{Cl}), 122.70(\mathrm{Ar}), 128.91$ (Ar), $129.15(\mathrm{Ar}), 132.53(\mathrm{Ar})$

f

$1.38\left(\mathrm{~d}, \mathrm{~J}=7,3 \mathrm{H}, \mathrm{CH}_{3}\right), 2.44\left(\mathrm{ABX}, \mathrm{J}=5.9,7.7,21.19\left(\mathrm{CH}_{3}\right), 28.42\left(\mathrm{CH}_{2}\right), 39.45(\mathrm{CH}), 57.5(-\mathrm{C} \equiv)\right.$, 16.4, 2H, $\left.\mathrm{CH}_{2}\right), 3.1(\mathrm{sex}, \mathrm{J}=7,1 \mathrm{H}, \mathrm{CH}), 7.28-68.93$ (三C-Cl), 127.03 (Ar), 127.25 (Ar), 128.96 $7.6(\mathrm{~m}, 5 \mathrm{H}, \mathrm{Ar})$ (Ar), 145.66 (Ar)

$\mathbf{g}$ 0.85-0.91 (m, 3H, $\left.\underline{\mathrm{CH}}_{3} \mathrm{CH}_{2}\right), 1.27-1.50\left(\mathrm{~m}, 14.73\left(\mathrm{CH}_{3}\right), 10.48\left(\mathrm{CH}_{2}\right), 23.48\left(\mathrm{CH}_{2}\right), 29.25\right.$, $\left.14 \mathrm{H}, \mathrm{CH}_{2}\right), 2.16\left(\mathrm{t}, \mathrm{J}=6.9,2 \mathrm{H}, \mathrm{CH}_{2} \mathrm{C} \equiv\right)$ $\left(\mathrm{CH}_{2}\right), 29.64\left(\mathrm{CH}_{2}\right), 29.96\left(\mathrm{CH}_{2}\right), 30.13\left(\mathrm{CH}_{2}\right)$, $30.32\left(\mathrm{CH}_{2}\right), 32.72\left(\mathrm{CH}_{2}\right), 57.62(-\mathrm{C} \equiv), 70.16(\equiv \mathrm{C}-$ Cl)

Table 7. ${ }^{1} \mathrm{H}$ and ${ }^{13} \mathrm{C}$ NMR Data of Gem-dichloroolefins $\mathbf{4 f}-\mathbf{g}$

\begin{tabular}{|c|c|c|}
\hline $\begin{array}{l}\text { Prod- } \\
\text { uct } 4 \\
\end{array}$ & $\begin{array}{l}{ }^{1} \mathrm{H} \mathrm{NMR}\left(\mathrm{CDCl}_{3}, 200 \mathrm{MHz}\right) \\
\delta, J(\mathrm{~Hz})\end{array}$ & $\begin{array}{l}{ }^{13} \mathrm{C} \mathrm{NMR}\left(\mathrm{CDCl}_{3}, 50 \mathrm{MHz}\right) \\
\delta, J \mathrm{C}, \mathrm{P}(\mathrm{Hz})\end{array}$ \\
\hline $\mathbf{f}$ & $\begin{array}{l}1.40\left(\mathrm{~d}, \mathrm{~J}=7,3 \mathrm{H}, \mathrm{CH}_{3}\right), 2.57(\mathrm{t}, \mathrm{J}=7.4,2 \mathrm{H}, \\
\left.\mathrm{H}_{2} \mathrm{C}-\mathrm{C}=\right), 2.99\left(\mathrm{sex}, \mathrm{J}=7.1,1 \mathrm{H}, \mathrm{Ar}-\mathrm{C}-\mathrm{CH}_{2}\right), \\
5.88\left(\mathrm{t}, \mathrm{J}=7,1 \mathrm{H}, \mathrm{CH}=\mathrm{CCl}_{2}\right), 7.27-7.52(\mathrm{~m}, 5 \mathrm{H}, \\
\text { Ar-H) }\end{array}$ & $\begin{array}{l}22.1\left(\mathrm{CH}_{3}\right), 38.71,39.68,121.30(\mathrm{HC}=), 127.00 \\
(\mathrm{Ar}), 127.09\left(=\mathrm{CCl}_{2}\right), 127.40(\mathrm{Ar}), 128.95(\mathrm{Ar}), \\
129.03(\mathrm{Ar}), 129.13(\mathrm{Ar}), 146.26(\mathrm{Ar})\end{array}$ \\
\hline $\mathbf{g}$ & $\begin{array}{l}0.97\left(\mathrm{t}, \mathrm{J}=6.8,3 \mathrm{H}, \underline{\mathrm{CH}}_{3} \mathrm{CH}_{2}\right), 1.25-1.58(\mathrm{~m}, \\
\left.14 \mathrm{H},\left(\mathrm{CH}_{2}\right) 8\right), 2.25(\mathrm{q}, \mathrm{J}=6.8,2 \mathrm{H}, \mathrm{CH} 2-\mathrm{C}=), \\
5.93(\mathrm{t}, \mathrm{J}=7.4,1 \mathrm{H}, \mathrm{CH}=)\end{array}$ & $\begin{array}{l}14.76\left(\mathrm{CH}_{3}\right), 23.49\left(\mathrm{CH}_{2}\right), 29.03\left(\mathrm{CH}_{2}\right), 29.94 \\
\left(\mathrm{CH}_{2}\right), 30.16\left(\mathrm{CH}_{2}\right), 30.21\left(\mathrm{CH}_{2}\right), 30.37\left(\mathrm{CH}_{2}\right) \text {, } \\
32.73\left(\mathrm{CH}_{2}\right), 120.76\left(=\mathrm{CCl}_{2}\right), 130.48(\mathrm{CH}=)\end{array}$ \\
\hline
\end{tabular}

Table 8. ${ }^{1} \mathrm{H}$ and ${ }^{13} \mathrm{C}$ NMR Data of Alkynes 7a-e

\begin{tabular}{|c|c|c|}
\hline $\begin{array}{l}\text { Prod- } \\
\text { uct } 7\end{array}$ & $\begin{array}{l}{ }^{1} \mathrm{H} \mathrm{NMR}\left(\mathrm{CDCl}_{3}, 200 \mathrm{MHz}\right) \\
\delta, J(\mathrm{~Hz})\end{array}$ & $\begin{array}{l}{ }^{13} \mathrm{C} \mathrm{NMR}\left(\mathrm{CDCl}_{3}, 50 \mathrm{MHz}\right) \\
\delta, J \mathrm{C}, \mathrm{P}(\mathrm{Hz})\end{array}$ \\
\hline $\mathbf{a}$ & $2.91(\mathrm{~s}, 1 \mathrm{H}, \mathrm{C} \equiv \mathrm{CH}), 7.1-7.45(\mathrm{~m}, 5 \mathrm{H}, \mathrm{Ar}-\mathrm{H})$ & $\begin{array}{l}77.92(\equiv \mathrm{C}-\mathrm{H}), 84.6(\mathrm{Ar}-\mathrm{C} \equiv), 122.61(\mathrm{Ar}), 128.75 \\
(\mathrm{Ar}), 129.20(\mathrm{Ar}), 132.53(\mathrm{Ar})\end{array}$ \\
\hline $\mathbf{b}$ & $\begin{array}{l}3.02(\mathrm{~s}, 1 \mathrm{H}, \mathrm{C} \equiv \mathrm{CH}), 3.80\left(\mathrm{~s}, 3 \mathrm{H}, \mathrm{OCH}_{3}\right), 6.81- \\
6.88(\mathrm{~m}, 2 \mathrm{H}, \mathrm{Ar}-\mathrm{H}), 7.36-7.47(\mathrm{~m}, 2 \mathrm{H}, \mathrm{Ar}-\mathrm{H})\end{array}$ & $\begin{array}{l}55.32\left(\mathrm{OCH}_{3}\right), 76.51(\equiv \mathrm{C}-\mathrm{H}), 85.0(\mathrm{Ar}-\mathrm{C} \equiv), 114.33 \\
(\mathrm{Ar}), 114.5(\mathrm{Ar}), 113.83,(\mathrm{Ar}), 160.0(\mathrm{Ar})\end{array}$ \\
\hline c & $\begin{array}{l}3.31(\mathrm{~s}, 1 \mathrm{H}, \mathrm{C} \equiv \mathrm{CH}), 3.90\left(\mathrm{~s}, 3 \mathrm{H}, \mathrm{OCH}_{3}\right), 6.91 \\
(\mathrm{t}, \mathrm{J}=7.8,2 \mathrm{H}, \mathrm{Ar}-\mathrm{H}), 7.25-7.4(\mathrm{~m}, 1 \mathrm{H}, \mathrm{Ar}-\mathrm{H}), \\
7.42-7.53(\mathrm{~m}, 1 \mathrm{H}, \mathrm{Ar}-\mathrm{H})\end{array}$ & $\begin{array}{l}55.36\left(\mathrm{OCH}_{3}\right), 79.6(\equiv \mathrm{C}-\mathrm{H}), 81.72(\mathrm{Ar}-\mathrm{C} \equiv), 110.60 \\
(\mathrm{Ar}), 120.28(\mathrm{Ar}), 130.25(\mathrm{Ar}), 133.61(\mathrm{Ar}), 160.47 \\
(\mathrm{Ar})\end{array}$ \\
\hline
\end{tabular}


$1.41\left(\mathrm{~d}, \mathrm{~J}=7.2,3 \mathrm{H}, \mathrm{CH}_{3}\right), 1.98-2.01\left(\mathrm{~m}, 1 \mathrm{H}, 20.83\left(\mathrm{CH}_{3}\right), 27.61\left(\mathrm{CH}_{2}\right), 38.95(\mathrm{CH}), 63.94(\equiv \mathrm{C}-\right.$ $\mathrm{C} \equiv \mathrm{CH}), 2.42-2.55\left(\mathrm{~m}, 2 \mathrm{H}, \mathrm{CH}_{2}\right), 2.91-3.12(\mathrm{~m}, \mathrm{H}), 83.0$ (-C $\left.\equiv\right), 126.52$ (Ar), 126.89 (Ar), 128.48 1H, CH), 7.19-7.39 (m, 5H, Ar-H) (Ar), $145.64(\mathrm{Ar})$

e $\quad 0.65\left(\mathrm{~m}, 3 \mathrm{H}, \mathrm{CH}_{3}\right), 1.1-1.62\left(\mathrm{~m}, 14 \mathrm{H}, \mathrm{CH}_{2}\right), 13.77\left(\mathrm{CH}_{3}\right), 18.13\left(\mathrm{CH}_{2}\right), 22.48\left(\mathrm{CH}_{2}\right), 28.34$ $1.93(\mathrm{t}, \mathrm{J}=2.6,1 \mathrm{H}, \mathrm{C} \equiv \mathrm{CH}), 2.17\left(\mathrm{td}, \mathrm{J}=2.6,7.0, \quad\left(\mathrm{CH}_{2}\right), 28.58\left(\mathrm{CH}_{2}\right), 29.13\left(\mathrm{CH}_{2}\right), 29.33\left(\mathrm{CH}_{2}\right)\right.$, $\left.2 \mathrm{H}, \mathrm{CH}_{2}-\mathrm{C} \equiv\right), 2.91-3.12$ $31.72\left(\mathrm{CH}_{2}\right), 67.61(\equiv \mathrm{CH}), 83.96(-\mathrm{C} \equiv)$

Support of this work by the CNRS for J. C. and R. W. is gratefully acknowledged.

(1) Seyferth, D.; Marmor, R. S. J. Organomet. Chem. 1973, 59, 237.

(2) Savignac, P.; Petrova, J.; Dreux, M.; Coutrot, P. Synthesis 1975, 535.

(3) Pflieger, D.; Muckensturm, B. Tetrahedron 1989, 45, 2031

(4) Villieras, J.; Perriot, P.; Normant, J. F. Synthesis 1975, 458.

(5) Atkinson, R. E.; Cadogan, J. I. G.; Dyson, J. J. Chem. Soc. 1967, 2542.

(6) Battacharya, A. K.; Thyagarajan, G. Chem. Rev. 1981, 81, 415.

(7) Kosolapoff, G. M. J Am. Chem. Soc. 1947, 69, 1002.

(8) Benkeser, R. A.; Smith, W. E. J Am. Chem. Soc. 1968, 90, 5307.

(9) Marinetti, A.; Savignac, P. submitted to Organic Synthesis.

(10) Guillemin, J. C.; Janati, T.; Guenot, P.; Savignac, P.; Denis, J. M. Angew. Chem. Int. Ed.Engl. 1991, 30, 196.

(11) Corey, E. J.; Fuchs, P. L.Tetrahedron Lett. 1972, 36, 3769.

(12) Colvin, E. W.; Hamill, B. J. J. Chem. Soc. Perkin Trans I 1977, 869.

(13) Gilbert, J. C.; Weerasooriya, U. J. Org. Chem. 1982, 47, 1837.

(14) Lowen, G. T.; Almond, M. R. J. Org. Chem. 1994, 59, 4548.

(15) Coutrot, P; Laurenco, C.; Normant, J. F.; Perriot, P.; Savignac, P.; Villieras Synthesis 1975, 458.

(16) Ott, E.; Bossaler, W. Ber. Deutsch. Chem. Ges. 1943, 76, 88.

(17) Hessler, J.C.Org. Syn. 1922, 2, 67; Org. Syn Collective Volume 1, 438.

(18) Vaughn, T. H. J . Am. Chem. Soc. 1933, 55, 3455.

(19) Bergmann, E.; Bondi, A. Ber. Deutsch. Chem. Ges. 1933, 66, 278.

(20) Quelet, R.; Golse, J. Compt. Rend. Acad. Sci. Paris 1946, 233, 159. 